\title{
Studies on the Cell-Wall Composition and Taxonomy of Actinomycetales and Related Groups
}

\author{
By C. S. CUMMINS and H. HARRIS \\ Departments of Bacteriology and Biochemistry, The London Hospital Medical \\ College, London, E. 1.
}

SUMMARY: The cell-wall compositions of 51 strains of Actinomyces, Nocardia, Streptomyces, Micromonospora, Mycobacterium and Propionibacterium have been investigated, together with those of 7 strains of Eumycetes. The cell walls of the actinomycetes were made up of sugars, amino sugars and amino acids (the latter few in number). The general pattern of components was thus identical with that previously found for Gram-positive bacteria. In the fungi, however, the mycelial walls were composed entirely of carbohydrate. These results suggest that the actinomycetes are not related to the fungi but should be classified with the bacteria proper. On the basis of cell-wall composition a classification of the actinomycetes is proposed, to consist of 3 families: Mycobacteriaceae containing the genera Mycobacterium, Nocardia and Corynebacterium; Streptomycetaceae containing Streptomyces and Micromonospora; and Actinomycetaceae with a single genus Actinomyces. The propionibacteria are probably related to Streptomyces. It is also suggested that a separate order Actinomycetales is unnecessary and that the families proposed can more suitably be included in the Eubacteriales.

Mycelium formation has always been the primary criterion for the inclusion of any species in the actinomycetes, but it is not always an easy one to apply as can be seen from the large number of different classifications proposed for these organisms in the last 50 years; Waksman (1950) outlined 14 in his monograph, and this is not an exhaustive list. There has been much disagreement, for example, about the position of corynebacteria and mycobacteria. Jensen (1931) thought that both should be included in the actinomycetes, while Stanier \& van Niel (1941) proposed that they should be omitted; Waksman \& Henrici (1943), adopting a middle course, excluded Corynebacterium from the Actinomycetales, but included Mycobacterium.

Apart from the uncertainty about which genera shall be included in the actinomycetes, there is considerable divergence of view about the arrangement and naming of those which are by common consent admitted. This point is well brought out by comparing Waksman \& Henrici's (1943) scheme, involving the four genera Actinomyces, Nocardia, Streptomyces and Micromonospora, with that adopted by Topley \& Wilson's Principles, 4th edition (1955) in which there is only one, Actinomyces. Although the latter classification is specifically stated to be a provisional one, the disparity between the two systems shows how much uncertainty still exists in the classification of these organisms.

The present paper records the results of an investigation into the cell-wall compositions of actinomycetes of different types, and discusses the application of the findings to the classification of these organisms. Our previous work (Cummins \& Harris, 1956a,b) has indicated that the composition of the 
bacterial cell wall is a character of some importance in classification and a preliminary investigation on a small number of strains of actinomycetes (Cummins \& Harris, 1956c) suggested that the same held good in this group also. Two recent papers, by Romano \& Sohler (1956) on the differentiation of Streptomyces and Nocardia by cell-wall composition, and by Hoare \& Work (1957) on the distribution of stereoisomers of diaminopimelic acid in Actinomycetales, have also indicated the value of this type of analysis in the taxonomy of micro-organisms. We have confined our attention entirely to Gram-positive species, and have not examined Gram-negative filamentous organisms such as Streptobacillus monitiformis or Fusiformis necrophorus (B. funduliformis).

\section{METHODS \\ Naming of strains}

We have in general used the names proposed by Waksman \& Henrici (1943), and therefore references in the present paper to Actinomyces, Nocardia, Streptomyces and Micromonospora have the meanings which those authors gave to them. However, in the case of any particular strain we have used the name the strain bore when we received it, whether or not this is in agreement with Waksman \& Henrici's system. This has meant, for example, that about half of the microaerophilic strains are referred to as Actinomyces israelii and not as $A$. bovis and that in the case of some of the aerobic saprophytes the genus is given as Actinomyces and not Streptomyces. We have not investigated the cultures in detail ourselves except to check them for purity.

\section{Sources of strains}

Actinomyces bovis and A. israelii. Details of the sources of these strains are given in Table 1.

Streptomyces and Actinomyces (aerobic). All from National Collection of Type Cultures (NCTC) or The National Collection of Industrial Bacteria (NCIB).

Micromonospora. Micromonospora sp. LSTM from London School of Hygiene and Tropical Medicine; Micromonospora sp. G1, from Dr M. R. J. Salton, Department of Bacteriology, University of Manchester; M. chalceae, strains S 3, S5 and C from Dr H. L. Jensen, Statens Planteavls Laboratorium, Lyngby.

Nocardia. N. caprae. Stock strain of London Hospital Bacteriology Department, origin unknown; N. leishmanii 658 , originally obtained as NCTC 658 and now discarded from National Collection of Type Cultures, as the original description was inadequate; $N$. gardneri NCTC 6531, $N$. asteroides $\mathrm{NCTC} 6761$ and $N$. farcinica NCTC 4524 from National Collection of Type Cultures.

Mycobacterium. M. tuberculosis B.C.G. This strain was obtained from Dr E. Lederer, Institut Pasteur, Paris, as the bacterial residue after extraction of the organisms with alcohol + ether and chloroform. The material showed apparently intact bacilli which still stained acid-fast. M. tuberculosis ' $\mathrm{C}$ ' (human strain) obtained as formalin killed culture from Dr A. B. Paterson, 
Central Veterinary Laboratory, Weybridge. M. phlei NCTC 8156 and M. smegmatis NCTC 8159 from National Collection of Type Cultures.

Propionibacterium. All five strains were obtained from the National Collection of Industrial Bacteria.

Table 1. Sources of strains of Actinomyces bovis and A. israelii

\begin{tabular}{|c|c|c|}
\hline $\begin{array}{l}\text { Name of } \\
\text { organism }\end{array}$ & $\begin{array}{l}\text { No. or name } \\
\text { of strain }\end{array}$ & Source \\
\hline \multirow[t]{5}{*}{ Actinomyces bovis } & $\left.\begin{array}{l}\text { NCTC } 9429 \\
\text { NCTC } 9430 \\
\text { NCTC } 9431\end{array}\right\}$ & $\begin{array}{l}\text { Isolated from cattle in U.K. by Mr M. B. } \\
\text { Hawksley, Bayer Biological Institute }\end{array}$ \\
\hline & $\left.\begin{array}{l}\text { NCTC } 4500 \\
\text { NCTC } 4501 \\
\text { NCTC } 4502\end{array}\right\}$ & $\begin{array}{l}\text { Isolated from cattle in Australia by Professor Carne } \\
\text { (see Erikson, 1940) }\end{array}$ \\
\hline & $\left.\begin{array}{r}2791 \\
975\end{array}\right\}$ & $\begin{array}{l}\text { Isolated from cattle in U.K.; received from } \\
\text { Mr Gordon Frazer, Royal (Dick) School of } \\
\text { Veterinary Studies, Edinburgh }\end{array}$ \\
\hline & $\left.\begin{array}{r}\mathbf{B . 1 0} \\
622\end{array}\right\}$ & $\begin{array}{l}\text { From Professor R. Lovell, Royal Veterinary } \\
\text { College. Bovine strains isolated in U.K. }\end{array}$ \\
\hline & $\begin{array}{l}\text { ATCC } 10048 \\
\text { ATCC } 12597\end{array}$ & $\begin{array}{l}\text { Isolated from pleural fluid in human case } \\
\text { Origin unknown }\end{array}$ \\
\hline \multirow[t]{2}{*}{ A. israelii } & $\begin{array}{l}\text { NCTC } 9765 \\
\text { ATCC } 12102 \\
\text { ATCC } 12103\end{array}$ & $\begin{array}{l}\text { Isolated in London Hospital from clinical case of } \\
\text { actinomycosis } \\
\text { Isolated from brain abscess in human case } \\
\text { Isolated from human case of cervico-facial actino- } \\
\text { mycosis }\end{array}$ \\
\hline & $\left.\begin{array}{l}\text { Bowdery } \\
\text { McGrath } \\
\text { Duncton } \\
\text { Hall } \\
\text { Kattenhorn } \\
\text { Goldworthy } \\
\text { Ingram } \\
\text { Denning }\end{array}\right\}$ & $\begin{array}{l}8 \text { strains received from Professor L. P. Garrod, } \\
\text { St Bartholomew's Hospital. All isolated from } \\
\text { human cases of actinomycosis }\end{array}$ \\
\hline
\end{tabular}

Fungi. The strains of Mucor mucedo 26441 and Rhizopus stolonifer 42844 were obtained from the Commonwealth Mycological Institute, Kew. Other fungi were stock strains of the Bacteriology Department, London Hospital.

\section{Culture media}

Solid media were not used because of the tendency of actinomycetes to produce a very adherent growth.

Actinomyces israelii and A. bovis. These species were grown in screw-capped bottles of glucose serum broth at $37^{\circ}$. The medium was prepared by adding $5 \mathrm{ml}$. of sterile $20 \%(\mathrm{w} / \mathrm{v})$ glucose and $5 \mathrm{ml}$. sterile horse serum to $100 \mathrm{ml}$. of tryptic digest broth.

Strains of Streptomyces and Nocardia, and aerobic strains of Actinomyces, were grown at $30^{\circ}$ in $1 \%(\mathrm{w} / \mathrm{v})$ glucose digest broth; $200 \mathrm{ml}$. amounts of medium were used in $1500 \mathrm{ml}$. conical flasks to give good aeration.

Micromonospora. The same medium was used as for Streptomyces, but because of the slow growth of these strains the normal procedure was modified. 
A preliminary culture of $10 \mathrm{ml}$. of glucose digest broth in a $50 \mathrm{ml}$. conical flask was incubated at $30^{\circ}$ for 3-4 days. The granular growth was then lightly ground in a TenBroeck tube under sterile conditions, and pipetted back into the original flask. The dispersed fragments grew rapidly and after another 3 or 4. days the whole $10 \mathrm{ml}$. of culture was used to inoculate $200 \mathrm{ml}$. of medium in a $1500 \mathrm{ml}$. flask, which was then incubated for a further 10 days.

Mycobacterium. M. phlei and M. smegmatis were grown in $5 \%(\mathrm{v} / \mathrm{v})$ glycerol broth at $37^{\circ}$. M. tuberculosis $\mathrm{H37} \mathrm{Rv}$ was grown in Tween-Dubos liquid medium.

Propionibacterium spp. These strains were grown in tomato-juice broth (Briggs, 1953) at $37^{\circ}$ in an atmosphere of hydrogen $+10 \%(\mathrm{v} / \mathrm{v}) \mathrm{CO}_{2}$.

Fungi. The strains of fungi were grown in glucose $(1 \%, \mathrm{w} / \mathrm{v})$ digest broth in conical flasks at $30^{\circ}$. The strains of Penicillium, Aspergillus, Mucor and Rhizopus grew rapidly and the cultures were killed by formalin after $24-48 \mathrm{hr}$. The pathogenic species grew more slowly and 10-14 days of incubation were necessary to obtain sufficient growth.

\section{Preparation of cell-wall fractions}

All cultures were killed by the addition of formalin ( $40 \%, \mathrm{w} / \mathrm{v}, \mathrm{HCHO})$ to a final concentration of $0.5 \%$. This was allowed to act at room temperature for $\mathbf{2 4} \mathrm{hr}$. and the organisms then removed by centrifugation and washed twice in distilled water. The cell-wall fractions were prepared as previously described (Cummins \& Harris, 1956a), except that in many cases it was found an advantage to break up firm nodules of growth by grinding the suspension thoroughly in a TenBroeck tube before disintegration. This preliminary grinding was essential in the case of fungal hyphae which otherwise were too long and coiled to be disrupted by the ballotini beads.

It is probable that in preparations from strains of Streptomyces and Micromonospora, particularly the latter, spore walls as well as mycelial walls were present, and the same is true of fractions from Mucor and Rhizopus where zygospore formation had occurred before the cultures were killed. The results obtained, however, suggest that either the number of spore-wall fragments present in each case was very small or that they have the same qualitative composition as the mycelial walls. The latter was certainly the case in a purified spore preparation from a strain of Streptomyces (see below).

\section{Chromatography}

The methods of hydrolysis and chromatography of cell-wall fractions were those described previously (Cummins \& Harris, 1956a). Separation of the stereoisomers of diaminopimelic acid (DAP) was as described by Hoare \& Work (1957).

\section{RESULTS}

The method of recording results is the same as that used in previous papers (Cummins \& Harris, 1956 $a, b$ ). The relative amounts of the different substances present in chromatograms have been arbitrarily scored as,,,++++++ \pm 
or trace; as before we have recorded only major components in the case of the amino acids. The substance we had previously called 'unknown hexosamine' has now been isolated and characterized by Strange (Strange, 1956; Strange \& Dark, 1956; Kent, 1957). We have referred to it in Tables $2-5$ by the name 'muramic acid' which Strange has suggested for it (see Work, 1957). The cyclic peptide of lysine and aspartic acid (Swallow \& Abraham, 1957; Abraham \& Swallow, personal communication), which we had previously found in lactobacilli occurred also in hydrolysates from some strains of Actinomyces bovis and is called aminosuccinoyllysine in the Tables. It almost certainly does not occur as such in cell walls but is formed by cyclization during acid hydrolysis. Its presence, however, probably indicates that the lysine and aspartic acid residues are linked in a specific way in the original material. It is not found, for example, in hydrolysates of those strains of Lactobacillus bifidus whose cell walls contain both aspartic acid and lysine (Cummins, Glendenning \& Harris, 1957).

The chromatographic method used separates LL-diaminopimelic acid from the DL- and DD- isomers, but the two latter run to the same position. They can be further differentiated by enzymic methods but this has not been done in the present instance. In fact DD-diaminopimelic acid seems to be very uncommon, and it has so far only been reported in the whole cells of strains of Micromonospora by Hoare \& Work (1957). Hoare \& Work also described an unknown substance which gave the same greenish colour with ninhydrin as diaminopimelic acid in the special solvent used to separate the isomers, but which ran more slowly than any of them. We have found a substance with similar properties in the cell walls of two strains of Micromonospora; it is recorded in Table 3 as 'slow-moving component'.

In certain strains of Actinomyces bovis an unidentified sugar was found. This moved faster than rhamnose in phenol/water, lutidine/water and butanol/ acetic acid/water and gave a colour reaction with aniline hydrogen phthalate very similar to the methylpentoses rhamnose and fucose. It is referred to in Table 2 as sugar component $\mathbf{P}$.

\section{Actinomyces israelii and $\mathrm{A}$. bovis}

The first point that emerges from a study of the results in Table 2 is the uniformity of cell-wall composition in the strains of Actinomyces israelii. All the 11 strains so named, together with two of those called $A$. bovis (ATCC 10048, ATCC 12597) seem to form a well-defined natural group in which the principal cell-wall components are galactose, glucosamine, muramic acid, alanine, glutamic acid and lysine. It was noted during the preparation of suspensions for disintegration that the growth of members of this group in glucose-serum broth was very uniform in type, and consisted of firm rounded or irregular masses at the bottom of an otherwise clear medium. After incubation had been continued for several days there was a tendency for looser floccules to develop but this did not destroy the characteristic 'breadcrumb' appearance which has been described previously as typical of microaerophilic parasitic actinomyces from human sources (Colebrook, 1920; Erikson, 1940; Rosebury, 1944; and others). 
Aminosuccinoyllysine •

++++++
$++++t+$.

Slow- moving component

告

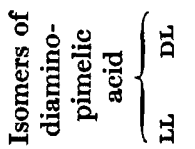

$\frac{*}{+}+$

$++$

$\pm+$

Glycine

$\begin{array}{ccc}+ & + & ++++++++ \\ \text { Lysine } & + & +++t++t+ \\ + & + & ++t++t+\end{array}$.

$\begin{array}{rll}+ & + & ++++++++++ \\ \text { Glutamic acid } & + & ++++++++++ \\ + & + & ++++++++++\end{array}$

Alanine $t+t++++++++$

$+\quad+t+++t++t$

$+++++++++$

$+++++$

$\cdot+t++++\cdot \cdot$

$++t++$

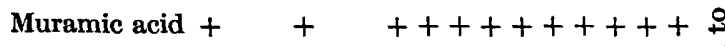

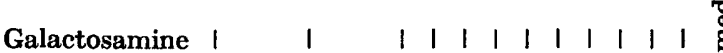

Glucosamine $t+t++++++++$

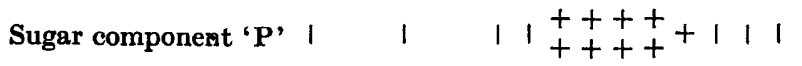

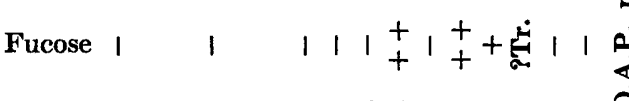

Mannose 1 I 1 |

$\begin{array}{llllllllllll}\text { Glucose } & 1 & 1 & 1 & 1 & 1 & 1 & 1 & 1 & 1 & 1 & 1\end{array}$

Galactose $+\underset{+}{+}+++++\underset{+}{+}+111++$

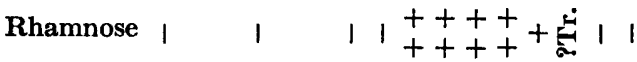

$\begin{array}{lllllllllll}\text { Arabinose } & 1 & 1 & 1 & 1 & 1 & 1 & 1 & 1 & 1 & 1 \\ +\end{array}$

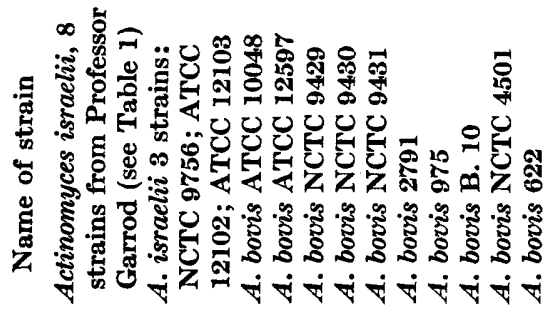




\section{Cell wall and taxonomy of Actinomycetales}

The results of cell-wall analysis of the strains of Actinomyces bovis, on the other hand (i.e. except ATCC 10048 and ATCC 12597), do not show the same homogeneity, and at least 2 subgroups can be recognized. The larger subgroup comprises 6 strains (B 10, 975, 2791; NCTC 9429-31) all isolated from cattle in various parts of the United Kingdom. The pattern of amino acids in the cell wall of these 6 strains (aspartic acid, lysine, glutamic acid and alanine) is identical with that previously found in various strains of lactobacilli (Cummins \& Harris, 1956a), and hydrolysates also contained the acid-resistant cyclic peptide mentioned above. The cell walls of these strains of $A$. bovis were also characterized by the presence of rhamnose and of the unidentified sugar component $(P)$. In addition, 3 of the 6 strains contained fucose. This unusual combination of amino acids and sugars made them easily identifiable. The growth of these strains in broth gave a generalized turbidity and a fine granular deposit, quite unlike that of the strains of $A$. israelii. None of them grew freely, and in the case of strain B10 there was insufficient material for a full analysis of the sugar components. There was no doubt, however, that B10 belonged to this subgroup.

Other organisms received as Actinomyces bovis were 3 strains examined by Erikson (1940) and originally isolated in Australia. Two of these (NCTC 4500 and NCTC 4502) had identical cell-wall compositions with an amino acid pattern unusually complex for Gram-positive bacteria since eight amino acids were present in relatively large amounts. These were aspartic acid, glutamic acid, serine, glycine, alanine, lysine, leucine and phenylalanine. The spots for alanine, glutamic acid and lysine were rather more intense than those for other amino acids. Glucosamine and muramic acid were present in cell-wall fractions from both strains, with rather smaller amounts of galactosamine. The results for these two organisms have not been incorporated in Table 2 to avoid complicating it unduly. The third strain, $A$. bovis NCTC 4501, is apparently a corynebacterium since cell-wall fractions from it contain arabinose, galactose, alanine, glutamic acid and diaminopimelic acid. Similar results were obtained with cell-wall fractions from strain $\mathbf{6 2 2}$, and it is very probable that this also is a diphtheroid. It was somewhat surprising to find that strain 4501 was very different from 4500 and 4502 , since Erikson found that suspensions of all 3 were agglutinated to similar titres by a serum prepared against one of them (Erikson, 1940; see p. 38 of her monograph).

The present results fully support the conclusions of Erikson (1940) and Thompson (1950) among others, that human and bovine strains of Actinomyces are distinct. To avoid the anomalous position created by having to call a predominantly human parasite by the specific term bovis, Erikson suggested that it would be reasonable to use the name $A$. israelii (originally proposed by Kruse, 1896), for strains of human origin which correspond in description to the organisms originally isolated by Wolff \& Israel (1891), and to regard strains of bovine origin as a distinct species, $A$. bovis. If our results are at all representative, however, there is very little justification for placing bovine strains in the same genus as strains of $\boldsymbol{A}$. israelii. In fact, of the 12 strains received as A. bovis, 2 (10048 and 12597) are identical with the human strains, 2 (4500 and 
4502) show a cell-wall pattern unlike anything hitherto recorded, 2 (4501 and 622) appear to be corynebacteria, and the remaining 6 form a homogeneous group which seems to be closely related to lactobacilli. If cell-wall composition is any guide to the classification of these strains the term $A$. bovis might well be discarded altogether, since the organisms usually given this name seem to be diverse generically and in most cases not related to microaerophilic strains of human origin.

Streptomyces, aerobic Actinomyces and Micromonospora spp.

These 13 strains are obviously closely related, the characteristic amino acids of their cell walls being alanine, glutamic acid, glycine and LL-diaminopimelic acid. It seems that LL-diaminopimelic acid is often accompanied by glycine in cell walls, since these two substances also occur together in propionibacteria (see Table 3), and in Clostridium relchii (Cummins \& Harris, unpublished observations; see also Work, 1957). The single strain of propionibacteria (Propionibacterium shermanii, NCIB 5964) in which DL- and not LL-diaminopimelic acid occurred contained virtually no glycine. The occurrence together of DL-diaminopimelic acid and glycine has so far only been reported in two unusual strains of staphylococci (Cummins \& Harris, 1956b).

The five strains of Micromonospora are distinguished by the fact that LLand DL-diaminopimelic acid are both present. Hoare \& Work (1957) have reported the presence of small amounts of DD-diaminopimelic acid, in addition to the other isomers, in whole cells of Micromonospora. It is not possible to say whether the DD-isomer occurs in their cell walls, as the method used in the present investigation did not separate it from the meso-(DL) isomer. Two of the five strains also contained the unidentified slow-moving component referred to above; its presence in strain LSTM has already been recorded by Hoare \& Work (1957).

In this group of non-acid-fast aerobic actinomycetes the majority of those examined contained no detectable amounts of hexose or pentose in their cell walls. In the three cases where hexoses were present, two strains had glucose only (Streptomyces antibioticus 8504 and $S$. olivaceus 8238 ) and one had glucose + galactose (S. aureofaciens 8234 ). The cell walls of the latter also contained galactosamine, glucosamine and muramic acid.

The cell-wall compositions of the two strains of Actinomyces graminis and the single strain of $\boldsymbol{A}$. hominis emphasize the fact that the aerobic saprophytic strains cannot satisfactorily be placed in the same genus as the microaerophilic ones, so that the generic term Actinomyces can be used for one or other, but not for both. Waksman \& Henrici (1943) concluded that it cannot, according to the Botanical code, be used for the aerobic strains, so that if used at all it must be applied to the microaerophilic parasitic species. They proposed to call these microaerophilic strains $\boldsymbol{A}$. bovis but we have indicated above why bovis is an unsuitable specific name for these organisms.

Finally, it may be of some interest to note that a single examination of cell walls from a purified spore suspension from Streptomyces sp. NCTC 7807 (Maxted strain) showed no qualitative difference in amino acid, amino sugar or 
Aminosuccinoyllysine



Slow-moving component

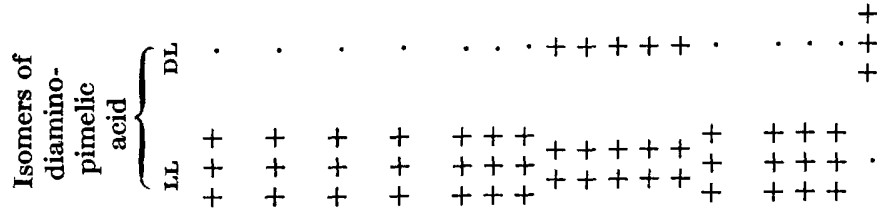

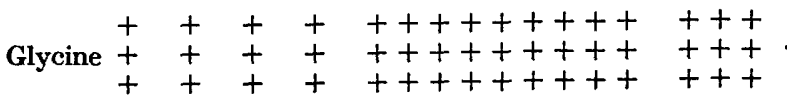

Lysine • •

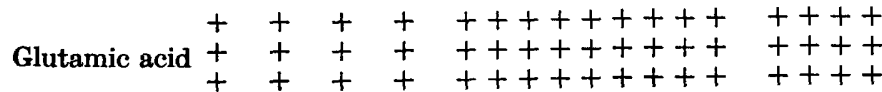

$++t+t++++++++t++$ Alanine $t+t+t++++++++++++$ $++t+t++++t+++t+$

Aspartic acid

Muramic acid ++++++++++++++++

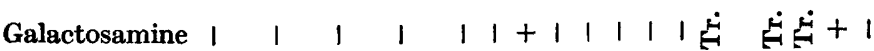

Glucosamine ++++++++++++++++

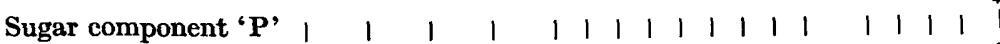

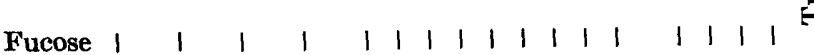

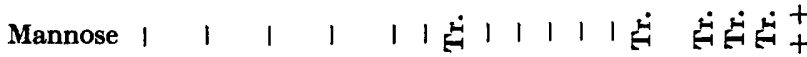

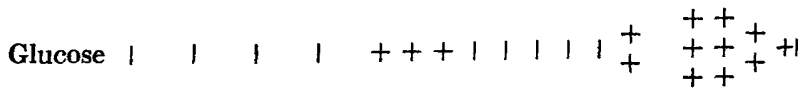

Galactose $1 \quad 1 \quad 1 \quad 1 \quad 1 \quad 1+1 \quad 1 \quad 1 \quad 1 \quad 1_{+}^{+}+\begin{aligned} & +++ \\ & ++\end{aligned}$

Rhamnose $1,1 \quad 1 \quad 1 \quad 1 \quad 1 \quad 1 \quad 1 \quad 1 \quad 1 \quad 1 \quad 1+1+1+$

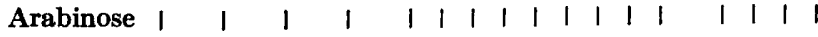

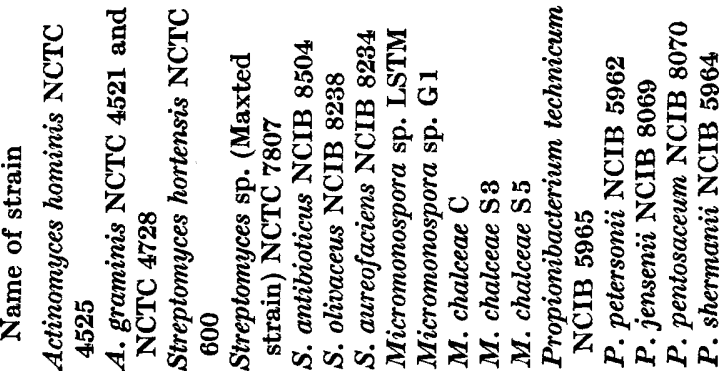


sugar composition as compared with the cell walls of the mycelium. The results of Erikson (1947), however, suggest that the spores have a considerably higher content of lipid than the mycelium, and much of this may be in the spore wall.

\section{Propionibacterium spp.}

It was somewhat surprising to find that the amino acid pattern of the cell walls of four strains of propionibacteria was the same as that in Streptomyces, although the propionibacteria had a more complex pattern of sugar components. The fifth strain, Propionibacterium shermanii 5964, differed considerably from the others. The significance of this difference is not known and we have not examined other strains of $\boldsymbol{P}$. shermanii to see whether the result is typical of this species.

\section{Nocardia and Mycobacterium spp.}

Electron micrographs of fractions from these strains prepared by the usual technique and assumed to consist mainly or entirely of cell walls showed large amounts of apparently amorphous material with few recognizable cell-wall fragments (Pl. 1, fig. 1). Chromatographic analysis of these fractions showed the presence of arabinose and galactose as characteristic sugars, and alanine, glutamic acid and diaminopimelic acid as the principal amino acids, but there were also considerable amounts of leucine, valine, threonine, serine, glycine and aspartic acid. It was noticed that oily droplets were formed during the preparation of acid hydrolysates, suggesting that much of the amorphous material visible in electron micrographs might be lipid. It has been known for some time (Anderson, Reeves \& Stodola, 1937; Anderson, Creighton \& Peck, 1940) that appreciable amounts of lipid remain in tubercle bacilli after extraction with neutral solvents, and that this firmly bound lipid can be released by the use of more vigorous solvents such as ethanol + ether containing $1 \%$ $(\mathrm{v} / \mathrm{v})$ conc. $\mathrm{HCl}$. In view of this, an investigation was made of the effects of acid and alkaline ethanol on suspensions of nocardias and mycobacteria both before and after disintegration. It was found that while acid ethanol $(0.5 \%(\mathrm{v} / \mathrm{v})$ conc. $\mathrm{HCl}$ ) had little or no effect, alkaline ethanol at $37^{\circ}$ removed a considerable amount of material. The method finally adopted was to extract the organisms with $0.5 \%(\mathrm{w} / \mathrm{v}) \mathrm{KOH}$ in ethanol for $48 \mathrm{hr}$. at $37^{\circ}$, after which the suspension was washed, first in neutral ethanol and then in distilled water, and the organisms disintegrated in the usual way. The insoluble fraction from these extracted suspensions was found to consist almost entirely of material having the usual appearance and dimensions of cell walls from disintegrated bacteria (see Pl. 1, fig. 2). On hydrolysis it was found that while the amounts of alanine, glutamic acid and diaminopimelic acid appeared to be unchanged, the other amino acids previously found were now absent or present only in traces. Some degradation of sugar components probably takes place in this procedure, but the main pattern was not altered. It seems obvious that alkaline ethanol removes a good deal of lipid from the insoluble fraction as prepared by disintegration in the Mickle shaker, and that this lipid may well be in the form of lipoprotein, since fewer amino acids are found after the alkaline ethanol 
Aminosuccinoyllysine . . . . . . . . .

Slow-moving component . . . . . . . . .

हैं
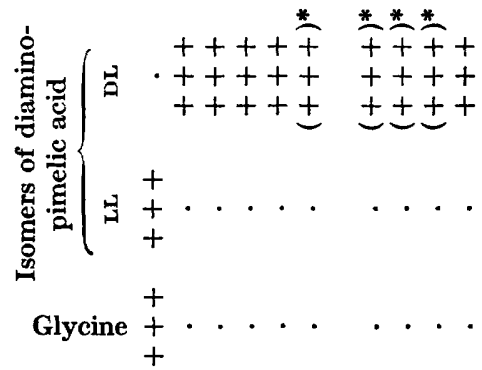

Lysine . . . . . . .

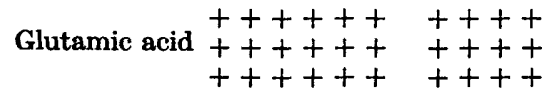

$\begin{array}{rr}t+++++ & ++++ \\ \text { Alanine }++++++ & ++++ \\ ++++++ & ++++\end{array}$

Aspartic acid . . . . . . . .

Muramic acid $+++++++++\$$

Galactosamine $+\begin{array}{llllllllll}1 & 1 & 1 & 1 & 1 & 1 & 1 & 1 & 1\end{array}$

Glucosamine $++++++t+t$

Sugar component ' $P$ '

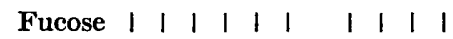

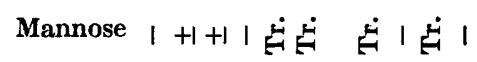

Glucose $\dot{\mu}+1+1 \quad$ 1 1 ।

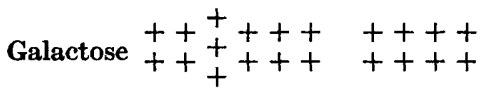

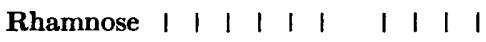

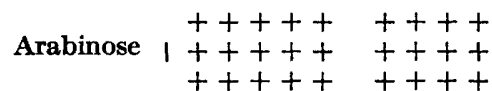

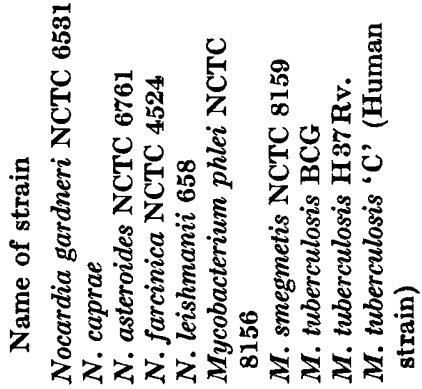


extraction. It is not possible, however, to say from the electron nicrographs whether this material is an integral part of the cell wall as it exists in the living organism, or whether it represents adherent remains of cytoplasmic lipid.

The presence of arabinose and galactose together with alanine, glutamic acid and meso-diaminopimelic acid suggests most strongly that both the nocardias and the mycobacteria are closely related to the corynebacteria, in which we had previously found this pattern of cell-wall components (Cummins \& Harris, 1956a). It has long been recognized on morphological grounds that such a relationship exists, and many suggested classifications of the actinomycetes have included Mycobacterium and less frequently Corynebacterium as constituent genera of the order Actinomycetales. The resemblances between their cell-wall compositions is so striking however, that one is forced to the conclusion that taxonomically nocardias, mycobacteria and corynebacteria should stand or fall together, so far as inclusion in any larger grouping is concerned.

It has already been noted that there is a clear distinction between the cell walls of Streptomyces and Nocardia (Cummins \& Harris, 1956a; Romano \& Sohler, 1956), and this is borne out in an interesting way by the strain Nocardia gardneri NCTC 6531. The cell-wall composition of this organism is quite different from that of the other strains of Nocardia examined (see Table 4). It is, however, virtually identical with that of Streptomyces aureofaciens NCIB 8234 and there seems little doubt that the strain $N$. gardneri NCTC 6531 should be reclassified as a Streptomyces.

The cell walls of Nocardia spp. are distinguished from those of Streptomyces spp. by the fact that they contain arabinose, and also because DL-diaminopimelic acid is present instead of the LL-isomer found in Streptomyces. Hoare \& Work (1957) have already shown that these genera can be separated by an examination of the type of diaminopimelic acid present in whole cellhydrolysates, and we have found in a small number of strains (Cummins \& Harris, unpublished) that the presence or absence of arabinose in hydrolysates of intact organisms can also be used to identify them. This would seem to be a useful additional method for distinguishing members of these two genera in cases of doubt, without the necessity for a full cell-wall analysis. The final identification of atypical strains of Nocardia or Streptomyces by morphology or fermentation tests may be somewhat difficult (see Gordon \& Mihm, 1957).

\section{DISCUSSION}

Relationship of the actinomycetes to bacteria and fungi. On account of their morphology, particularly in the case of Streptomyces and Micromonospora, it has often been suggested that the actinomycetes form a group intermediate between the bacteria and the fungi. Most of the evidence, however (for example the absence of true nuclei and the size of the mycelium) points to a far closer relationship to the Eubacteriales than to the Eumycetes (see Waksman, 1957). Avery \& Blank (1954) were unable to detect cellulose or chitin in strains of Actinomyces, Nocardia, Streptomyces or Micromonospora, and concluded that 
they had nothing in common, chemically, with the true fungi. The present results show that the cell walls of the actinomycetes are complexes of sugars, amino sugars and a few amino acids (usually three or four) and are thus identical in general structure with cell-wall fractions from Gram-positive bacteria (Salton, 1953; Cummins \& Harris, 1956a,b). Two particularly characteristic features are the presence of the substituted hexosamine muramic acid, and the restricted number of amino acids, among which either diaminopimelic acid or lysine, but not both, is a major component.

Table 5. Composition of walls of various fungal mycelia

Sugars and amino sugars

Penicillium species Aspergillus species Rhizopus stolonifer 26441

Mucor mucedo 42844 Microsporum gypseum Tricophyton mentagrophytes Epidermophyton floccosum

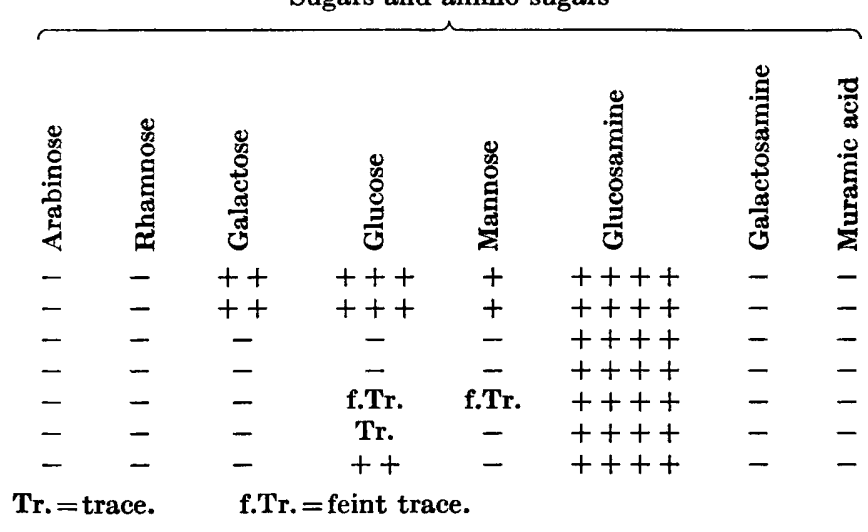

As a comparison we have examined by the same technique hydrolysates of mycelial walls from a limited number of species of fungi, and the results are recorded in Table 5. Apart from traces of the amino acids most commonly found in proteins, which probably come in this case from a slight degree of cytoplasmic contamination, the walls of these fungi consist entirely of carbohydrate. There is, moreover, no trace of muramic acid, although large amounts of glucosamine are present. These results seem to indicate a fundamental biochemical distinction between fungi and actinomycetes. The substance muramic acid in particular seems to be a characteristic bacterial product in both Gram-positive and Gram-negative species (Cummins \& Harris, 1956 $a, b$, and unpublished observations), and its complete absence from these fungi is striking.

It may also be noted in passing that there is a difference in composition between the walls of the 2 strains of Aspergillus and Penicillium examined, and those of Mucor and Rhizopus, since the latter consisted entirely of glucosamine while the former contained appreciable amounts of hexoses in addition. This difference is interesting since it has been previously suggested that cellwall composition in fungi may have taxonomic significance (see Frey, 1950).

The classification of the actinomycetes. If the organisms which we have examined are classified solely on cell-wall composition, a tentative scheme can he drawn up which is outlined in Table 6. In this scheme the genera proposed 
are those of Waksman \& Henrici (1943) except that it is suggested that strains of animal origin should not be included in Actinomyces at least until their position has been clarified by further work. One feature of the proposed classification is that Nocardia is separated from Actinomyces and placed instead in the family Mycobacteriaceae together with Mycobacterium and Corynebacterium.

Table 6. Suggested classification of actinomycetes, based on cell-wall composition

\begin{tabular}{|c|c|c|c|}
\hline \multirow[b]{2}{*}{ Family } & \multirow[b]{2}{*}{ Genus } & \multicolumn{2}{|c|}{ Characteristic cell-wall components } \\
\hline & & Sugars & Amino acids \\
\hline Mycobacteriaceae & $\begin{array}{l}\text { Nocardia } \\
\text { Mycobacterium } \\
\text { Corynebacterium }\end{array}$ & $\begin{array}{c}\text { Arabinose, } \\
\text { galactose }\end{array}$ & $\begin{array}{l}\text { Alanine, glutamic acid, } \\
\text { DL-diaminopimelic acid }\end{array}$ \\
\hline Actinomycetaceae & Actinomyces & Galactose & $\begin{array}{l}\text { Alanine, glutamic acid, } \\
\text { lysine }\end{array}$ \\
\hline Streptomycetaceae & $\begin{array}{l}\text { Streptomyces } \\
\text { Micromonospora } \\
\text { (Propionibacterium) }\end{array}$ & $\begin{array}{l}\text { No charac- } \\
\text { teristic sugar }\end{array}$ & $\begin{array}{l}\text { Alanine, glutamic acid, } \\
\text { glycine, LL-diaminopimelic } \\
\text { acid* }\end{array}$ \\
\hline
\end{tabular}

* In Micromonospora DL-diaminopimelic acid is present in addition.

This arrangement is the same as that suggested by Bisset \& Moore (1949) on the basis of cell morphology. There seems to be every reason to regard Mycobacteria, Nocardia and Corynebacteria as closely related and the fact that all have the same characteristic cell-wall composition, distinguished particularly by the pentose arabinose, is an additional indication that they should be classified together.

A further property possessed by many species of Nocardia is that of acidfastness. This is a difficult character to use in classification, since it is dependent to a large extent on the age of the culture, the medium and the length of time since the strain was originally isolated. It seems most likely that all strains of Nocardia are at least potentially acid-fast, so that the possession of this character is significant but its absence is not. The distinction between the two genera Nocardia and Mycobacterium is very blurred, and organisms such as $M$. phlei may show a branched mycelium at some stage of growth, while cultures of Nocardia asteriodes may at times be composed almost entirely of acid-fast rods. The distinction between Corynebacterium and Nocardia is more clear-cut in this respect, but at least some corynebacteria can be acid-fast (e.g. Corynebacterium equi; see Jensen, 1953, p. 82).

As far as other genera in the proposed classification are concerned, little comment is needed. Almost all authorities are agreed that Streptomyces and Micromonospora should be placed in the same family, and the results of cellwall analysis support this. A more detailed investigation of a series of strains of propionibacteria will be needed, however, before the relationship between them and the streptomyces can be definitely established. We have therefore included Propionibacterium in Table 6, but placed it in brackets to indicate its rather doubtful position in the Streptomycetaceae. Hungate (1946) described 
an anaerobic organism Micromonospora propionici which exhibited a characteristic propionic acid fermentation, so that there may well be a relationship between the two groups. In the case of Actinomyces, it seems best to leave this for the moment as a genus containing a single species, $A$. israelii. Cell-wall composition gives no indication of any close relationship between $A$ ctinomyces and Corynebacterium, nor between Actinomyces and Lactobacillus bifidus (see Cummins et al. 1957); the products of fermentation of glucose are also different in all three groups (Pine, 1956; Pine \& Howell, 1956).

A final question which seems to us to need discussion is whether it is desirable to have two separate orders, Actinomycetales and Eubacteriales. These are usually distinguished on the grounds that the bacteria proper do not show mycelium formation and branching, while the actinomycetes do. This is certainly truc of strains of Streptomyces and Micromonospora in which a nonfragmenting branched mycelium is a characteristic feature. On the other hand, corynebacteria do not usually exhibit either branching or a mycelial type of growth, and yet there is every reason to suppose that they are very closely related to the nocardias in which both of these characters are present. It has already been pointed out that the general pattern of cell-wall components in actinomycetes is the same as that in Gram-positive bacteria. Although the subject is too large for a full discussion here, it seems to us that a good case can be made for abandoning the order Actinomycetales, and for classifying actinomycetes together with the bacteria in the Eubacteriales. Many organisms will produce filamentous forms under certain conditions, for example, in magnesium-deficient media (Webb, 1948, 1949). The ability to grow in the form of branched filaments could have evolved independently in several different groups, in which case it would be unwise to use it too rigidly as a differential criterion, particularly if a phylogenetic system of classification is ultimately to be adopted.

We are grateful to Professor C. F. Barwell and Dr S. T. Cowan for advice and criticism during the preparation of the manuscript, to Miss Sylvia Start for much assistance with the chromatography, to Miss Olivia Glendenning for help in the preparation of cell-wall fractions and to Dr R. C. Valentine of the National Institute for Medical Research, Mill Hill, for the electron micrographs. We would also like to thank all those who sent cultures for investigation.

\section{REFERENCES}

Anderson, R. J., Creighton, M. M. \& Peck, R. L. (1940). The chemistry of the lipids of tubercle bacilli. LX. Concerning the firmly bound lipids of the avian tubercle bacillus. J. biol. Chem. 133, 675.

Anderson, R. J., Reeves, R. E. \& Stodola, F. H. (1937). The chemistry of the lipids of tubercle bacilli. LI. Concerning the firmly bound lipids of the human tubercle bacillus. J. biol. Chem. 121, 649 .

Avery, R. J. \& Blank, F. (1954). On the chemical composition of the cell walls of the Actinomycetales and its relation to their systematic position. Canad. $J$. Microbiol. 1, 140.

Bisset, K. A. \& Moore, F. W. (1949). The relationship of certain branched bacterial genera. J. gen. Microbiol. 3, 387. 
Briggs, M. (1953). The classification of lactobacilli by means of physiological tests. J. gen. Microbiol. 9, 234.

Colsebrook, L. (1920). The mycelial and other micro-organisms associated with human actinomycosis. Brit. J. exp. Path. 1, 197.

Cummins, C. S., Glendenning, O. \& Harris, H. (1957). Composition of the cell wall of Lactobacillus bifidus. Nature, Lond. 180, 337.

Cummins, C. S. \& Harris, H. (1956a). The chemical composition of the cell wall in some Gram-positive bacteria and its possible value as a taxonomic character. J. gen. Microbiol. 14, 583.

Cummins, C. S. \& Harris, H. $(1956 b)$. The relationships between certain members of the staphylococcus-micrococcus group as shown by their cell wall compositions. Int. Bull. Bact. Nomen. \& Taxon. 6, 111.

Cummins, C. S. \& Harris, H. (1956c). A comparison of cell wall composition in Nocardia, Actinomyces, Mycobacterium and Propionibacterium. J. gen. Microbiol. 15, ix.

Erikson, D. (1940). Pathogenic anaerobic organisms of the actinomyces group. Med. Res. Coun. spec. Rep. Ser., Lond. no. 240.

Erikson, D. (1947). Differentiation of the vegetative and sporogenous phases of the actinomycetes. 1. The lipid nature of the outer wall of the aerial mycelium. J. gen. Microbiol. 1, 39.

Frex, R. (1950). Chitin und Zellulose in Pilzzellwänden. Ber. schweiz. bot. Ges. 60, 199.

Gordon, R. E. \& Minm, J. M. (1957). A comparative study of some strains received as Nocardiae. J. Bact. 73, 15.

Hoare, D. S. \& Work, E. (1957). The stereoisomers of $\alpha, \epsilon$-diaminopimelic acid. 2. Their distribution in the bacterial order Actinomycetales and in certain Eubacteriales. Biochem. J. 65, 441.

Hungate, R. E. (1946). Studies on cellulose fermentation. II. An anaerobic cellulose decomposing actinomycete Micromonospora propionici n.sp. J. Bact. 51, 51.

Jensen, H. L. (1931). Contribution to our knowledge of the Actinomycetales. II. The definition and subdivision of the genus Actinomyces, with a preliminary account of Australian soil actinomycetes. Proc. Linn. Soc. N.S.W. 56, 345.

Jensen, H. L. (1953). In Symposium on Actinomycetales. VIth Int. Congr. Microbiol. pp. 69-88. Rome: Fondazione Emanuele Paterno.

KeNT, L. H. (1957). The structure of muramic acid. Biochem. J. 67, 5P.

Kruse, W. (1896). Systematik der Streptothriceen. In Flügge's Die Mikroorganismen, 2, 48. (Quoted by Erikson, 1940.)

Pine, L. (1956). Fixation of carbon dioxide by Actinomyces and Lactobacillus bifidus. Proc. Soc. exp. Biol., N.Y. 93, 468.

Pine, L. \& Howell, A. (1956). Comparison of physiological and biochemical characters of Actinomyces spp. with those of Lactobacillus bifidus. J. gen. Microbiol. 15, 428.

Romano, A. H. \& Sohler, A. (1956). Biochemistry of the Actinomycetales. II. A comparison of the cell wall compositions of species of the genera Streptomyces and Nocardia. J. Bact. $72,865$.

Rosebury, T. (1944). The parasitic actinomycetes and other filamentous microorganisms of the mouth. Lact. Rev. 8, 189.

Salton, M. R. J. (1953). Studies of the bacterial cell wall. IV. The composition of the cell walls of some Gram-positive and Gram-negative bacteria. Biochim. biophys. Acta, 10, 512.

Stanier, R. Y. \& van Niel, C. B. (1941). The main outlines of bacterial classification. J. Bact. 42, 437.

Strange, R. E. (1956). The structure of an amino sugar present in certain spores and bacterial cell walls. Biochem. J. 64, 23 P. 
Journal of General Microbiology, Vol. 18, No. 1

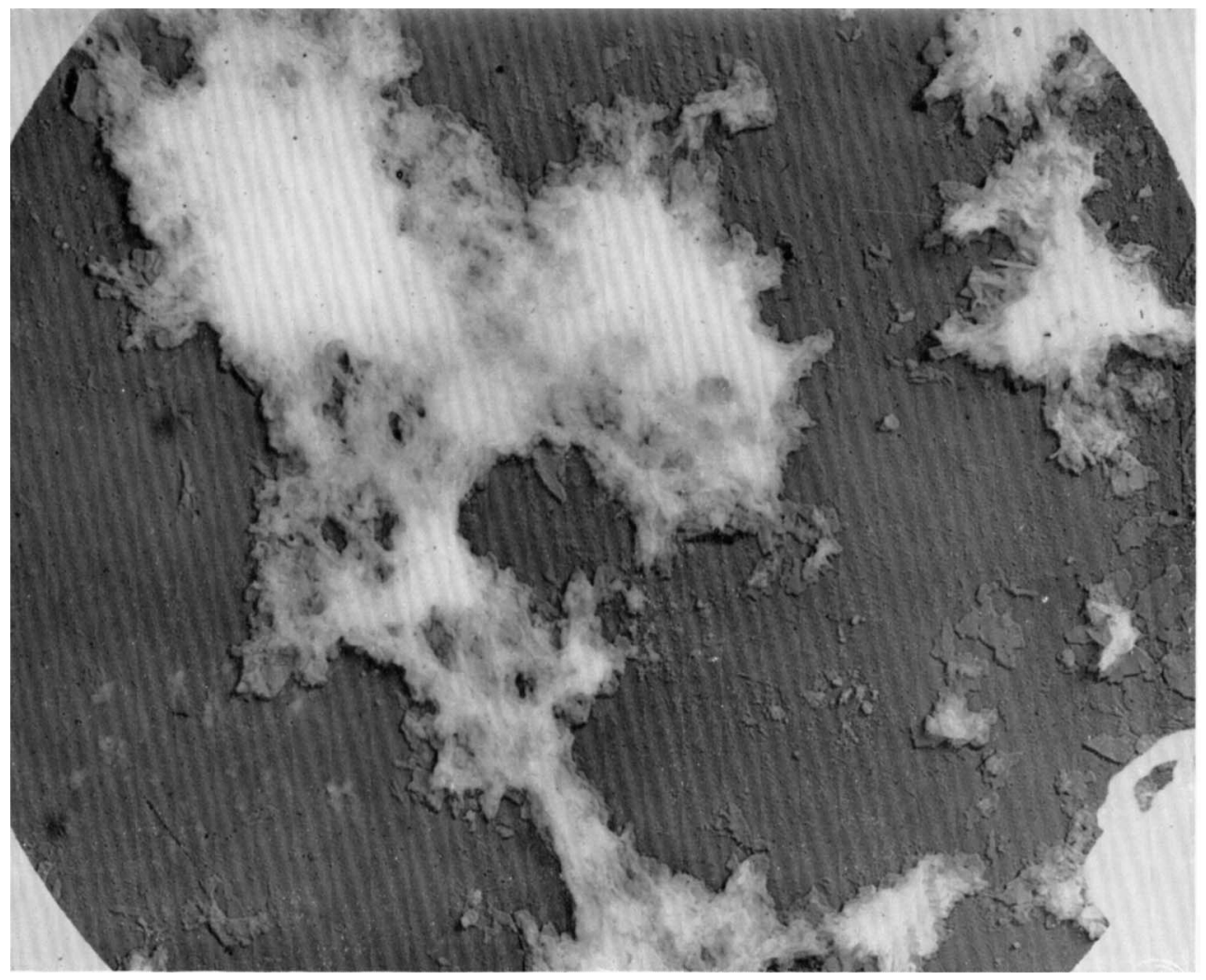

Fig. 1

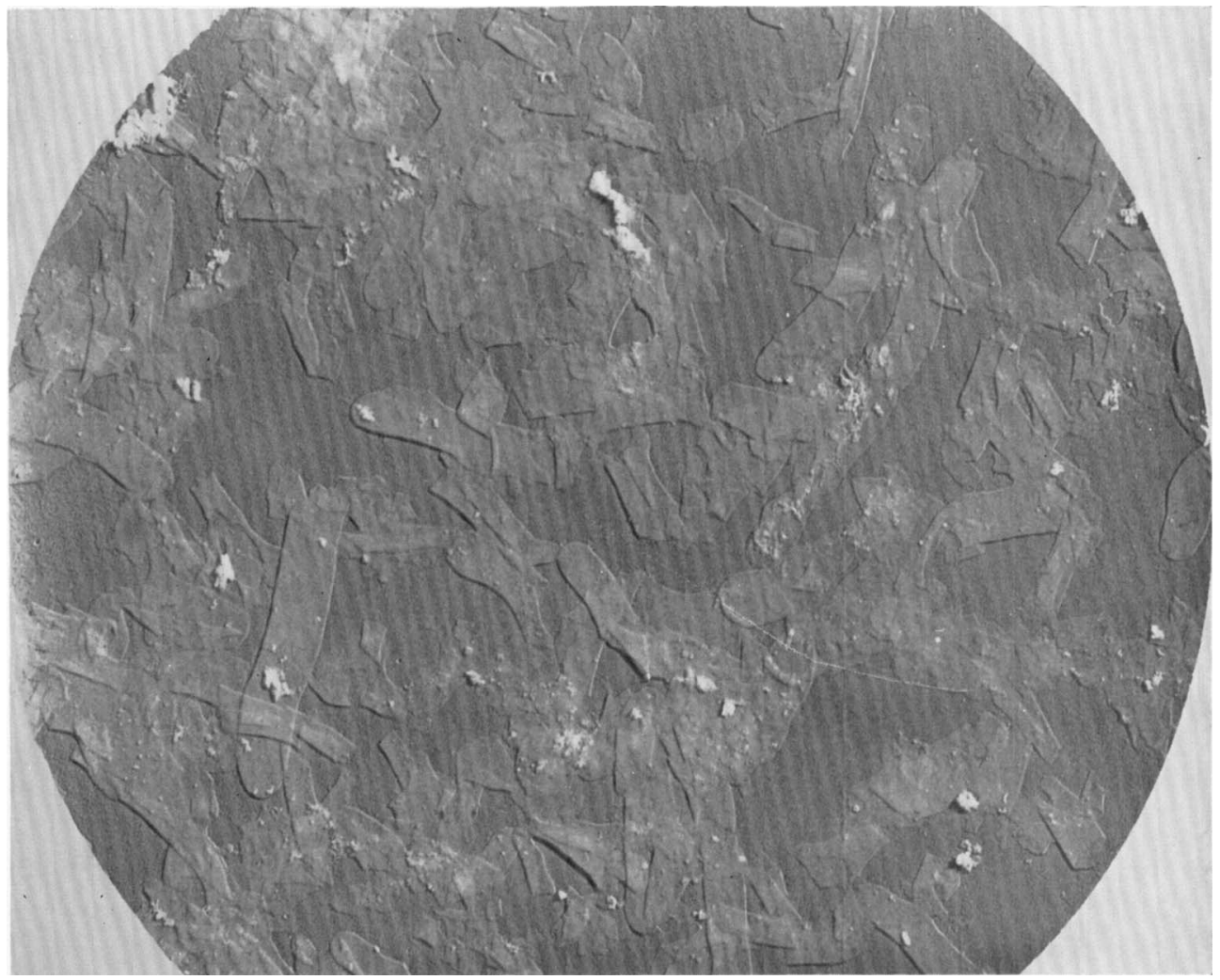

Fig. 2

C. S. Cummins \& H. Harris-Cell wall and taxonomy of actinomycetales. Plate 1 

Strange, R. E. \& Dark, E. A. (1956). An unidentified amino sugar present in cell walls and spores of various bacteria. Nature, Lond. 177, 186.

Swallow, D. L. \& Abraham, E. P. (1957). A cyclic derivative of aspartyllysine obtained from bacitracin A. Biochem. J. 65, $39 \mathrm{P}$.

Thompson, L. (1950). Isolation and comparison of actinomyces from human and bovine infections. Proc. Mayo Clin. 25, 81.

Topley \& Wilson's Principles of Bacteriology \& Immunity (1955). Fourth edition, pp. 457, ed. Wilson, G. S. \& Miles, A. A. London: Arnold.

Waksman, S. A. (1950). The Actinomycetes, their Nature, Occurrence, Activities and Importance. Waltham, Mass., U.S.A.: Chronica Botanica Co.

Waksman, S. A. (1957). Species concept among the actinomycetes with special reference to the genus Streptomyces. Bact. Rev. 21, 1.

Waksman, S. A. \& Henrici, A. T. (1943). The nomenclature and classification of the actinomycetes. J. Bact. 46, 337.

WebB, M. (1948). The influence of magnesium on cell division. 1. The growth of Clostridium welchii in complex media deficient in Magnesium. J.gen. Microbiol. 2, 275.

WEBB, M. (1949). The influence of magnesium on cell division. 2. The effect of magnesium on the growth and cell division of various bacterial species in complex media. J. gen. Microbiol. 3, 410.

WoLfF, M. \& Israel, J. (1891). Utber Reincultur des Actinomyces und seine Uebertragbarkeit auf Thiere. Virchow's Arch. 126, 11.

Work, E. (1957). Biochemistry of the bacterial cell wall. Nature, Lond. 179, 841.

\section{EXPLANATION OF PLATE}

Magnification in both photographs $c . \times 12,000$.

Fig. 1. Cell-wall fraction from suspension of Mycobacterium tuberculosis strain $\mathrm{C}$ (human) which had been extracted with neutral solvents before disintegration.

Fig. 2. Cell-wall fraction from suspension of $M$. tuberculosis strain C extracted with alkaline ethanol before disintegration. 